\title{
The role of adipokines in skeletal muscle inflammation and insulin sensitivity
}

\author{
Thomas Nicholson ${ }^{1}$, Chris Church², David J. Baker ${ }^{2}$ and Simon W. Jones ${ }^{1,3^{*}}$
}

\begin{abstract}
Background: There is currently an unmet clinical need to develop better pharmacological treatments to improve glucose handling in Type II Diabetes patients with obesity. To this end, determining the effect of obesity-associated adipokines on skeletal muscle insulin sensitivity has emerged as an important area of drug discovery research. This review draws together the data on the functional role of adipokines on skeletal muscle insulin signalling, highlights several understudied novel adipokines and provides a perspective on the direction of future research.

Main body: The adipokines leptin, resistin, visfatin and adiponectin have all been shown to affect skeletal muscle insulin sensitivity by impacting on the activity of components within insulin signalling pathways, affecting GLUT4 translocation and modulating insulin-mediated skeletal muscle glucose uptake. Furthermore, proteomic analysis of the adipose tissue secretome has recently identified several novel adipokines including vaspin, chemerin and pref-1 that are associated with obesity and insulin resistance in humans and functionally impact on insulin signalling pathways. However, predominantly, these functional findings are the result of studies in rodents, with in vitro studies utilising either rat L6 or murine C2C12 myoblasts and/or myotubes. Despite the methodology to isolate and culture human myoblasts and to differentiate them into myotubes being established, the use of human muscle in vitro models for the functional validation of adipokines on skeletal muscle insulin sensitivity is limited.

Conclusion: Understanding the mechanism of action and function of adipokines in mediating insulin sensitivity in skeletal muscle may lead to the development of novel therapeutics for patients with type 2 diabetes. However, to date, studies conducted in human skeletal muscle cells and tissues are limited. Such human in vitro studies should be prioritised in order to reduce the risk of candidate drugs failing in the clinic due to the assumption that rodent skeletal muscle target validation studies will to translate to human.
\end{abstract}

Keywords: Obesity, Adipokines, Inflammation, Skeletal muscle, Myotubes, Insulin signalling, Type II diabetes

\section{Background}

Type II diabetes (T2D) is a chronic metabolic disorder that carries a significant and increasing economic burden [1]. Unfortunately, there is no cure for T2D and treatments are limited. Furthermore, the inability of patients to maintain plasma glucose concentrations is associated with a number of chronic pathologies, including microvascular disease and macrovascular diseases such as stroke and coronary artery disease [2].

\footnotetext{
*Correspondence: s.w.Jones@bham.ac.uk

'MRC-ARUK Centre for Musculoskeletal Ageing Research, Medical School, Queen Elizabeth Hospital, University of Birmingham, Birmingham B15 2WB, UK

${ }^{3}$ Institute of Inflammation and Ageing, MRC-Arthritis Research UK Centre for Musculoskeletal Ageing Research, Queen Elizabeth Hospital, Mindelsohn Way, Edgbaston, Birmingham B15 2TT, UK

Full list of author information is available at the end of the article
}

One of the major treatment strategies for T2D patients is to increase insulin sensitivity, either through lifestyle modifications such as weight loss, or via the administration of insulin-sensitising drug therapies including Biguanides such as Metformin [3, 4] and Thiazolidinediones [5]. Alternatively, some patients are prescribed Sulphoylureas, which stimulate insulin secretion [6, 7]. However, these medications are associated with significant side-effects when taken chronically and can become ineffective as disease progresses [8-13]. Therefore, there is great unmet clinical need to develop more effective and more targeting therapeutics for T2D patients.

In attempting to identify new therapies, skeletal muscle has emerged as an important area of drug discovery research. Muscle metabolic function is considered central to maintaining insulin sensitivity $[14,15]$, being responsible 
for up to $80 \%$ of insulin-mediated glucose uptake in healthy individuals [16]. Indeed, T2D patients display impaired skeletal muscle glucose uptake in response to insulin. Given the association of obesity and T2D and the paradigm of adipose tissue as an endocrine organ [17-19], recent studies have examined the cross-talk between skeletal muscle and adipose tissue in the context of insulin resistance. In obese individuals, adipose tissue is known to become more "inflammatory", with an increase in the infiltration of immune cells including T-cell subsets [20] and inflammatory M1 macrophages [21], which drive the production of pro-inflammatory adipokines associated with insulin resistance $[22,23]$.

Importantly, secretome analysis of human adipocyte culture medium has identified over 200 adipokines [24]. Therefore, understanding the functional and mechanistic role of these adipokines on skeletal muscle insulin signalling could identify novel targets for therapeutic intervention. Here we summarise the key studies conducted to date on the functional role of adipokines on skeletal muscle insulin signalling, highlight several understudied novel adipokines and provide a perspective on the direction of future research.

\section{Established well known Adipokines}

The adipokines leptin, adiponectin, resistin and visfatin are known mediators of inflammation and have all been implicated in metabolic diseases, including T2D. Below, we highlight studies conducted on these adipokines which relate to their functional role in skeletal muscle insulin signalling, and summarise these findings in Table 1 in relation to animal and human data.

\section{Leptin}

The role of leptin as an inflammatory adipokine in metabolic disorders is well studied. Systemic levels of leptin positively correlate with both BMI and waist circumference, and are associated with the development of insulin resistance $[25,26]$. Several studies have reported that leptin impacts on skeletal muscle insulin signalling. Stimulation of the rat L6 skeletal muscle cell line with recombinant leptin reduced phosphorylation of the insulin receptor substrate-1 (IRS-1) and impaired glucose uptake, suggesting that leptin promotes insulin resistance [27]. However, in contrast, leptin stimulation of murine $\mathrm{C} 2 \mathrm{C} 12$ myotubes was found to increase glucose uptake, whilst overexpression of leptin in a 'skinny' mouse model increased insulin sensitivity $[28,29]$. These contrasting data highlight the need to conduct functional studies on leptin in human myotubes. To this end, Yau et al. reported that leptin increased AKT phosphorylation in commercially available human myotubes [30]. However, to date the functional role of leptin on human skeletal muscle insulin signalling is still understudied.

\section{Adiponectin}

Adiponectin is considered to be a beneficial adipokine in relation to metabolism; plasma concentrations inversely correlate with weight, central obesity, risk of T2D and insulin resistance in humans [31, 32]. Furthermore, maintenance of a low calorie intake increases both adipocyte expression of adiponectin and circulatory concentrations [33].

Three different molecular weight isoforms of adiponectin are found in the circulation, of which the high molecular-weight isoform is beloved to be the most functional in terms of glucose homeostasis. Functional studies suggest that adiponectin promotes insulin sensitivity in skeletal muscle. In $\mathrm{C} 2 \mathrm{C} 12$ myocytes, adiponectin increases fatty acid oxidation via sequential activation of AMPK, p38 MAPK and PPAR $\alpha[34,35]$ and promotes glucose uptake [35]. Similarity, in L6 myotubes adiponectin induces glucose transporter 4 (GLUT4) translocation and glucose uptake [36]. In vivo, adiponectin knockout mice demonstrate an obese, insulin resistant phenotype, whereas systemic administration of adiponectin, or its delivery as a transgene direct to skeletal muscle, improves insulin sensitivity [37-40]. Adiponectin has also been shown to induce fat oxidation via AMPK activation in human myotubes, and further, this mechanism was found to be impaired in myotubes from obese T2D patients [41]. Critically, this suggests that the function of adiponectin as a promoter of insulin sensitivity translates to humans. Furthermore, it suggests that impairment of adiponectin function in skeletal muscle of obese T2D patients may contribute in the development of insulin resistance.

\section{Resistin}

First identified in murine adipocytes as a secreted protein capable of inducing insulin resistance [42], resistin is a pro-inflammatory adipokine that induces the secretion of TNF $\alpha$ and IL- 6 from various cell types including PBMCs and pancreatic acinar cells [43, 44].

The correlation between plasma resistin with both obesity and insulin resistance in humans support a role for resistin in the development of insulin resistance [45, 46]. In vitro, studies have demonstrated a reduction in AKT phosphorylation and glucose uptake in $\mathrm{C} 2 \mathrm{C} 12$ and L6 myotubes stimulated with recombinant resistin [47-49]. However, at present few studies have investigated the functional role of resistin in the development of insulin resistance in human skeletal muscle cells.

\section{Visfatin}

Visfatin (also called NAMPT) is termed an 'adipokine-enzyme' due to the NAD biosynthesis function of its intracellular form (iVisfatin/iNAMPT), also exists extracellularly (eVisfatin/eNAMPT) [50, 51]. eVisfatin is primarily 
Table 1 Evidence for the role of known adipokines in mediating skeletal muscle insulin sensitivity

\begin{tabular}{|c|c|c|c|c|}
\hline \multirow[t]{2}{*}{ Adipokine } & \multirow{2}{*}{$\begin{array}{l}\text { Association with obesity } \\
\text { and/or T2D in humans }\end{array}$} & \multicolumn{2}{|c|}{ Adipokine effect on insulin signalling in animal models } & \multirow{2}{*}{$\begin{array}{l}\text { Adipokine effect on insulin } \\
\text { signalling in human skeletal } \\
\text { muscle }\end{array}$} \\
\hline & & In Vivo & In Vitro & \\
\hline \multirow[t]{2}{*}{ Leptin } & \multirow[t]{2}{*}{ Increased $[25,26,127]$} & \multirow{2}{*}{$\begin{array}{l}\text { Overexpression of leptin in a } \\
\text { skinny mouse model increased } \\
\text { insulin sensitivity [29]. } \\
\text { Administration of leptin } \\
\text { (12-15 days) reversed insulin } \\
\text { resistance in obese wistar rats } \\
\text { [128]. } \\
\text { Leptin reversed high fat diet } \\
\text { induced skeletal muscle insulin } \\
\text { resistance in rats, indirectly via } \\
\text { reducing intramuscular } \\
\text { triglycerides not though direct } \\
\text { modulation of insulin signalling } \\
\text { [129]. }\end{array}$} & $\begin{array}{l}\text { Recombinant leptin reduces IRS-1 } \\
\text { phosphorylation and glucose } \\
\text { uptake in L6 myotubes [27]. }\end{array}$ & \multirow[t]{2}{*}{$\begin{array}{l}\text { Increased phosphorylation of } \\
\text { AKT in commercially available } \\
\text { primary human myotubes [30]. }\end{array}$} \\
\hline & & & $\begin{array}{l}\text { Recombinant leptin increased } \\
\text { glucose uptake in C2C12 } \\
\text { myotubes [28]. } \\
\text { Acute (10mins-1 h) stimulation of } \\
\text { L6 Myotubes directly increased } \\
\text { glucose uptake via a PI3K-dependent } \\
\text { pathway. Leptin pre-treatment (10 min) } \\
\text { of L6 myotubes inhibits insulin } \\
\text { stimulated glucose uptake [130]. } \\
24 \text { h Pre-treatment of L6 myotubes had } \\
\text { no effect on glucose uptake but did } \\
\text { inhibit adiponectin stimulated glucose } \\
\text { uptake [131]. }\end{array}$ & \\
\hline \multirow[t]{2}{*}{ Adiponectin } & \multirow[t]{2}{*}{ Decreased $[31,32]}$. & $\begin{array}{l}\text { Adiponectin knockout mice } \\
\text { demonstrate an obese and } \\
\text { insulin resistant phenotype } \\
{[37,39] \text {. }}\end{array}$ & $\begin{array}{l}\text { Promotes glucose uptake in both } \\
\text { C2C12 and L6 Myotubes }[35,36] \text {. }\end{array}$ & \multirow[t]{2}{*}{$\begin{array}{l}\text { Induces fat oxidation through } \\
\text { activation of AMPK in myotubes } \\
\text { from lean subjects. Mechanism } \\
\text { impaired in myotubes from T2D } \\
\text { patients [41]. }\end{array}$} \\
\hline & & $\begin{array}{l}\text { Systemic administration and } \\
\text { overexpression of adiponectin } \\
\text { drives increased insulin } \\
\text { sensitivity in insulin resistant } \\
\text { mice }[38,40] .\end{array}$ & $\begin{array}{l}\text { Recombinant adiponectin increased } \\
\text { glucose uptake via AMPK mediated } \\
\text { reorganisation of the actin cytoskeleton } \\
\text { and GLUT4 translocation via an } \\
\text { independent mechanism [130]. }\end{array}$ & \\
\hline \multirow[t]{2}{*}{ Resistin } & \multirow[t]{2}{*}{ Increased $[45,46]$. } & $\begin{array}{l}\text { Administration of resistin ( } 6 \text { days) } \\
\text { to wild type mice induces a state } \\
\text { of insulin resistance [132]. }\end{array}$ & $\begin{array}{l}\text { Recombinant resistin Impaired insulin } \\
\text { signalling and glucose uptake in both } \\
\text { C2C12 and L6 myotubes }[48,49] \text {. }\end{array}$ & \multirow[t]{2}{*}{ Unknown } \\
\hline & & $\begin{array}{l}\text { Targeted reduction of resistin in } \\
\text { insulin resistant mice via } \\
\text { antisense oligodeoxynucleotide } \\
\text { restored hepatic but not skeletal } \\
\text { muscle insulin sensitivity [133]. }\end{array}$ & & \\
\hline \multirow[t]{2}{*}{ Visfatin } & \multirow[t]{2}{*}{ Increased [134-136]. } & \multirow[t]{2}{*}{$\begin{array}{l}\text { Visfatin overexpression in rats } \\
\text { increased whole body insulin } \\
\text { sensitivity and adipose tissue } \\
\text { and liver IRS-1 phosphorylation } \\
\text { in response to insulin [56]. }\end{array}$} & $\begin{array}{l}\text { Stimulated glucose uptake and } \\
\text { increased GLUT4 membrane } \\
\text { translocation and mRNA and } \\
\text { protein expression in C2C12 } \\
\text { myotubes via AMPK p38 MAPK } \\
\text { signalling [57]. }\end{array}$ & \multirow[t]{2}{*}{ Unknown } \\
\hline & & & $\begin{array}{l}\text { Increased glucose uptake in rat EDL } \\
\text { muscle [137]. }\end{array}$ & \\
\hline
\end{tabular}

produced and secreted from visceral adipose tissue, where it is more highly expressed in obese individuals [52]. Similarly, higher systemic levels of evisfatin are associated with obesity, ageing and the development of T2D [53-55].

Regarding the role of visfatin in mediating insulin sensitivity, overexpression of visfatin in male wistar rats increased whole body insulin sensitivity [56], and in adipose tissue and liver, promoted insulin-mediated IRS-1 phosphorylation [56]. Data on the function of visfatin in skeletal muscle insulin sensitivity is limited to studies in rodents. Visfatin increases glucose transport in rat skeletal muscle fibres [57]. Furthermore, in C2C12 myotubes, visfatin activates AMPK/p38 MAPK, induces GLUT4 expression and translocation, and promotes glucose uptake [57]. Based on these data, similar insulin sensitizing effects may occur in human skeletal muscle.

\section{Novel Adipokines}

In addition to the well-known adipokines, proteomic studies of adipose tissue have identified several less characterised adipokines that may also play important roles in mediating skeletal muscle insulin sensitivity. At present the functional effects of the majority of these novel adipokines on human skeletal muscle insulin sensitivity $\mathrm{s}$ poorly understood. Some of the more prominent novel adipokines are discussed below and also summarised in Table 2 . 


\section{Vaspin}

First reported as a $47 \mathrm{KDa}$ protein in the visceral adipose tissue of the genetically obese OLETF rats [58], administration of vaspin to obese mice increased insulin sensitivity and glucose tolerance [59]. Additionally, subcutaneous adipose tissue expression of leptin, resistin and TNF $\alpha$ was suppressed, whilst GLUT4 and adiponectin expression was increased following vaspin administration [59]. Similar increases in insulin sensitivity have since been reported in $\mathrm{db} / \mathrm{db}$ and C57BL6 mice following recombinant vaspin delivery [60]. Central administration of vaspin to obese mice resulted in a sustained suppression of appetite that resulted in reduced bodyweight and plasma glucose concentrations [61]. Furthermore, transgenic mice overexpressing vaspin displayed improved glucose tolerance, reduced systemic IL-6 concentrations and were protected from obesity when fed a high fat diet [62].

In humans, vaspin expression has been reported in several tissues including subcutaneous adipose tissue, skin, stomach and skeletal muscle [61, 63, 64]. Serum concentrations of vaspin in non-diabetic and diabetic patients positively correlate with BMI, bodyweight and impaired glucose tolerance [65-68]. Given the functional effects of vaspin demonstrated in the rodent models, its increased expression with BMI in humans may reflect a compensatory mechanism.

The effect of vaspin on insulin signalling and metabolism in human skeletal muscle is currently undetermined. Similarly, the mechanism of action and receptor for vaspin has also not been elucidated. Recently, it was reported that in HepG2 cells vaspin binds glucose-regulated protein (GRP78), a 7KDa voltage-dependent anion channel. Further, stimulation of $\mathrm{H}$-4-II-E-C3 cells with recombinant vaspin activated AKT and AMPK signalling pathways, which was prevented by GRP78 inhibition [62]. Vaspin may therefore mediate its effects on insulin signalling via binding to GRP78. However, at present the expression of GRP78 has not been profiled in human adipose or skeletal muscle tissue, nor the functional studies conducted in human skeletal cells to validate GRP78 as the vaspin receptor.

\section{Fibroblast growth factor 21}

FGF-21 is established as a key mediator of fat oxidation and in energy homeostasis [69-71]. Numerous studies report that serum concentrations of FGF-21 are elevated in obese individuals and positively correlate with insulin resistance, BMI, \% fat mass and circulatory concentrations of leptin and LDL [72-75]. Although predominantly produced by the liver, FGF-21 is also expressed in adipose tissue, where it is more highly expressed in both obese and diabetic mouse models.

In vivo, administration of FGF-21 to mice fed a high fat diet decreased intramuscular triglyceride content, increased insulin sensitivity and glucose uptake, and elevated secretion of adiponectin from adipocytes [76]. Continuous cerebral administration of FGF-21 for 2 weeks increased whole body insulin sensitivity in rats with dietary-induced obesity [77], whilst daily intravenous or subcutaneous delivery of FGF-21 for 6 weeks improved glucose handling in diabetic rhesus monkeys [78]. Following such positive effects on insulin sensitivity and glucose tolerance, two FGF-21 mimetics (LY2405319 and PF-05231023) have progressed to phase 1 clinical trials (NCT01869959, NCT01923389) [79-83], and antibodies targeting FGFR1c/ b-Klotho have been developed [84, 85].

With regards to a direct functional role of FGF-21 in skeletal muscle, incubation of isolated mouse EDL muscle with FGF-21 increased insulin-stimulated glucose uptake, and in human myotubes FGF-21 increased both basal and insulin-stimulated glucose uptake [86]. Furthermore, FGF-21 has also shown to prevent palmitate-induced insulin resistance in primary human myotubes by inhibiting stress kinases and NF- $\mathrm{B}$ [87].

\section{Chemerin}

Chemerin, was initially described as a novel chemoattractant for macrophages and dendritic cells via activation of several GPCRs including CMKLR1/ChemR23, GPR1, and CCRL2 [88, 89]. More recent data suggests chemerin plays an important role in the differentiation of human adipocytes [90, 91], and in the development of insulin resistance. Circulatory concentrations of chemerin are associated with obesity, diabetes and metabolic syndrome [92-94] . Furthermore, adipose tissue from obese subjects exhibits greater secretion of chemerin [95].

At present, in vivo studies have drawn differing conclusions regarding the role of chemerin in the development of insulin resistance. Becker et al. reported that overexpression of chemerin increased insulin resistance in LDLreceptor deficient mice fed a high fat diet, as evidenced by reduced insulin-mediated AKT phosphorylation [96]. Importantly this effect was only observed in skeletal muscle, and not liver or pancreas [96]. Additionally, glucose handling and serum insulin concentrations were reduced by chemerin administration to both obese and diabetic mice [97]. However, no such effect was observed following chemerin administration to control mice. In contrast, Takahashi et al. showed that chemerin knockout mice display increased skeletal muscle insulin resistance, due to a disruption of hepatic glucose production and reduced insulin secretion from pancreatic Beta cells [98]. Additionally, transgenic mice overexpressing chemerin were reported to have increased skeletal muscle insulin sensitivity [98].

In vitro studies provide support for chemerin as a driver of insulin resistance. Pre-treatment of $\mathrm{C} 2 \mathrm{C} 12$ myotubes with chemerin reduced insulin-stimulated glucose uptake, while increasing the secretion of pro-inflammatory cytokines including IL-6 and TNF- $\alpha$ [99]. Additionally, 
Table 2 Evidence for the role of novel adipokines in mediating insulin sensitivity

\begin{tabular}{|c|c|c|c|c|}
\hline \multirow[t]{2}{*}{ Adipokine } & \multirow{2}{*}{$\begin{array}{l}\text { Association with obesity } \\
\text { and/or T2D in humans }\end{array}$} & \multicolumn{2}{|c|}{ Adipokine effect on insulin signalling in animal models } & \multirow{2}{*}{$\begin{array}{l}\text { Adipokine effect on insulin } \\
\text { signalling in human skeletal } \\
\text { muscle }\end{array}$} \\
\hline & & In Vivo & In Vitro & \\
\hline FGF-21 & Increased [86]. & $\begin{array}{l}\text { Increased insulin sensitivity and glucose } \\
\text { uptake in mice, via FGF- } 21 \text { mediated } \\
\text { increases in adiponectin production } \\
\text { and secretion from adipocytes [76]. }\end{array}$ & $\begin{array}{l}6 \mathrm{~h} \text { incubation of mouse EDL } \\
\text { muscle with FGF- } 21 \text { resulted } \\
\text { in a } 54 \% \text { increase in insulin } \\
\text { stimulated glucose uptake } \\
\text { [86]. }\end{array}$ & $\begin{array}{l}\text { Directly increased glucose } \\
\text { uptake in primary human } \\
\text { myotubes [86]. } \\
\text { Prevents palmitate-induced } \\
\text { insulin resistance in primary } \\
\text { human myotubes by } \\
\text { inhibiting stress kinases and } \\
\text { NF-KB [87]. }\end{array}$ \\
\hline
\end{tabular}

$24 \mathrm{~h}$ pre-treatment reduces insulin stimulated glucose uptake in C2C12 myotubes in a dose dependent manor [99]. (n) response insulin in skeletal muscle, but not liver or pancreas [96].

knockout mice display increased skeletal muscle insulin resistance while transgenic mice exhibit increased skeletal muscle insulin resistance [98].

Acute chemerin treatment exacerbated glucose intolerance and lowered serum insulin levels in obese and diabetic mice. No effect observed in normoglycemic mice [97].

Decreased $[115,116,139]$. Administration of recombinant CTRP3 directly lowers glucose levels in normal and insulin-resistant ob/ob mice [140].

Overexpression of CTRP3 improved insulin sensitivity in HFD fed mice [141].
Overexpression or direct administration of RBP4 increased insulin resistance in mice. RBP4 knockout improves insulin sensitivity in mice [144].

Reducing circulating RBP4 in obese mice models improved glucose tolerance and increased insulin stimulated glucose uptake in skeletal muscle up to $60 \%$ [145].

Vaspin treatment increased insulin sensitivity and glucose tolerance in obese and diabetic mice $[59,60]$.

transgenic mice overexpressing vaspin displayed improved glucose tolerance and were protected from obesity when challenged with a high fat diet [62].
Administration of recombinant CTRP3

to L6 myotubes had no effect on glucose uptake [140].

Increased glucose uptake and GLUT 4 mRNA expression in insulin resistant adipocytes [142].

unknown

Unknown

Unknown Unknown

Unknown
24 h chemerin Increased insulin resistance and reduced insulin stimulated glucose uptake in primary human myotubes, mediated by increased ERK signalling [95]. 
Table 2 Evidence for the role of novel adipokines in mediating insulin sensitivity (Continued)

\begin{tabular}{|c|c|c|c|c|}
\hline \multirow[t]{2}{*}{ Adipokine } & \multirow{2}{*}{$\begin{array}{l}\text { Association with obesity } \\
\text { and/or T2D in humans }\end{array}$} & \multicolumn{2}{|c|}{ Adipokine effect on insulin signalling in animal models } & \multirow{2}{*}{$\begin{array}{l}\text { Adipokine effect on insulin } \\
\text { signalling in human skeletal } \\
\text { muscle }\end{array}$} \\
\hline & & In Vivo & In Vitro & \\
\hline Pref-1 & Increased [101]. & $\begin{array}{l}\text { Overexpression in mice drives } \\
\text { insulin resistance via decreased } \\
\text { adipose tissue and skeletal muscle } \\
\text { glucose uptake and impaired } \\
\text { skeletal muscle insulin signalling } \\
\text { [105]. }\end{array}$ & Unknown & $\begin{array}{l}4 \text { Day exposure to primary } \\
\text { human myotubes from lean, } \\
\text { obese and T2D subjects had } \\
\text { no effect on glucose uptake } \\
{[106] .}\end{array}$ \\
\hline Follistatin-like 1 & Increased [108]. & Unknown & $\begin{array}{l}\text { Blunts insulin signalling- } \\
\text { adipocytes [108]. }\end{array}$ & unknown \\
\hline Omentin-1 & Decreased $[146,147]$. & Unknown & $\begin{array}{l}\text { omentin-1 induced AKT } \\
\text { phosphorylation and enhanced } \\
\text { insulin-stimulated glucose } \\
\text { uptake in human adipocytes } \\
\text { [123]. }\end{array}$ & $\begin{array}{l}\text { Unknown } \\
\text { Unknown }\end{array}$ \\
\hline Lipocallin-14 & Unknown & $\begin{array}{l}\text { Over expression in diet induced } \\
\text { obese mice reduced glucose and } \\
\text { insulin levels while improving } \\
\text { glucose tolerance [124]. }\end{array}$ & Unknown & \\
\hline
\end{tabular}

treatment of primary human myotubes with recombinant chemerin reduced insulin-stimulated glucose uptake [95]. Further cross-talk studies with primary human myocytes and myotubes, particularly from obese and diabetic cohorts may help to clarify the function of chemerin in human metabolic disease states.

\section{Pref-1}

Preadipocyte factor 1 (Pref- 1 ) is a transmembrane protein processed to generate a circulating form, which is also known as Foetal Antigen 1 (FA1) [100]. Studies have described an association of increased Pref-1/FA1 serum concentrations with obesity and T2D [101, 102]. Pref-1 is also reported to negatively regulate adipogenesis, with Pref-1 deficient mice displaying significant obesity and stunted growth $[103,104]$. Overexpression of Pref- 1 in mice promotes a lipodystrophic phenotype and insulin resistance via decreased skeletal muscle glucose uptake and impaired skeletal muscle insulin signalling [105].

In humans, Pref-1 stimulation of myotubes from lean, obese, and T2D patients with did not affect insulin sensitivity. However Pref- 1 did induce the production of the pro-inflammatory IL-6 and CCL2 [106], and thus chronic exposure of muscle to pathological levels of Pref-1 may impair insulin sensitivity indirectly. Clearly, further studies utilising human myotubes are warranted to fully determine the functional role of Pref- 1 in skeletal muscle insulin sensitivity.

\section{Follistatin-like 1}

Follistatin-like 1 (FSTL1) is a glycoprotein with homology to osteonectin and its expression is associated with systemic inflammatory diseases including rheumatoid arthritis, lupus and ulcerative colitis. Several in vitro studies have established FSTL1 as a pro-inflammatory cytokine. For example, over-expression of FSTL1 in the fibroblast-like COS7 cell line or in human U937 monocytes induced the secretion of pro-inflammatory cytokines IL-6, TNF- $\alpha$ and IL-1 $\beta$ [107].

With regards to adipose biology, FSTL1 is highly expressed in 3 T3-L1 pre-adipocytes and is implicated in their differentiation [108, 109]. Furthermore, stimulation of 3 T3-L1 adipocytes with recombinant FSTL1 inhibited insulin signalling [108] In vivo, increased adipose tissue expression of FSTL1 is reported in the leptin-deficient ob/ ob mouse, and in humans serum levels of FSTL1 positively correlate with BMI [108]. Despite being expressed and secreted by human myotubes [110] no studies to date have reported the functional effects of FSTL1 on skeletal muscle insulin signalling, using either rodent or human cells.

\section{SPARC}

SPARC (osteonectin) was first discovered as a glycoprotein secreted from bone. However, it is now known that SPARC is also expressed and secreted from adipose tissue. SPARC adipose tissue expression is increased in dietary-induced obesity in rats [111]. In humans, SPARC is secreted from adipose tissue, implicated in adipocyte differentiation and hyperplasia [112], and its expression in adipose tissue correlates with fat mass [113]. Furthermore, serum levels of SPARC are associated with insulin resistance, dyslipidemia and inflammation in patients with gestational diabetes mellitus (GDM) [114]. Mechanistically, overexpression of SPARC in 3 T3-L1 adipocytes downregulated GLUT4 expression and inhibited insulin-stimulated glucose uptake [111]. Given these data, it seems likely that SPARC would impair skeletal muscle insulin signalling. At present, these 
studies have not yet been conducted and so its functional role in skeletal muscle is not established.

\section{CTRP3}

CTRP3 is a member of a family of proteins which includes adiponectin. Similarly to adiponectin, CTRP3 has been identified as an anti-inflammatory adipokine. In humans, CTRP3 levels in the serum are lower in obese subjects compared to normal-weight individuals $[115,116]$, and negatively correlate with markers of insulin resistance [116]. In vitro, CTRP3 inhibits LPS-induced expression of pro-inflammatory cytokines in human macrophages [117], whilst RNAi-mediated knockdown in preadipocytes increased the expression of chemokines and reduced adiponectin expression [118]. Its functional role in skeletal muscle insulin signalling has not been characterised.

\section{Omentin-1}

Originally identified as a lectin-binding protein [119], Omentin-1 (intelectin-1) is highly expressed in visceral adipose tissue [120]. In humans, systemic concentrations and adipose tissue expression of Omentin- 1 are lower in obese individuals [120] and negatively correlate with BMI and insulin resistance [120]. Furthermore, lower serum levels of omentin-1 are observed in newly diagnosed T2D patients and its secretion from human adipose tissue is decreased by both insulin and glucose [121, 122].

In vitro, studies support a role for Omentin-1 as an antiinflammatory adipokine, which suppresses the activity of TNF- $\alpha$ in vascular inflammation via inhibiting p38 and JNK pathways. A role for Omentin-1 in promoting insulin sensitivity is supported by studies in human adipocytes where recombinant Omentin-1 induced AKT phosphorylation and enhanced insulin-stimulated glucose uptake [123]. Thus far, studies to determine its functional role in skeletal muscle using either rodent models or human tissue have not been reported.

\section{Lipocalins}

Lipocalins are a functionally diverse group of proteins with a highly conserved tertiary structure that have been implicated in inflammation and immune responses. Importantly, a number of lipocalins, most notably lipocalin-2 (LCN2) and RBP4 have been associated with adipose tissue expression and obesity. Recently, a new member of the lipocalin family was identified, termed lipocalin-14 (LNC14), which in mice was found to be predominantly expressed in WAT and was downregulated in dietary-induced obese mice [124]. Furthermore, adenovirus over-expression of LCN14 in obese mice improved insulin sensitivity [124].

\section{Conclusions}

Obesity and its associated conditions including insulin resistance and T2D are increasing globally, resulting in substantial socioeconomic costs. Since adipose tissue secretes a number of adipokines that can have both positive and negative effects on insulin sensitivity and metabolism, targeting adipokine signalling has emerged as a potential area to identify and develop novel therapeutics. Therefore, given that muscle is the major organ for insulin-stimulated glucose uptake, understanding the function and mode-ofaction of such adipokines on skeletal muscle is critical.

To address this need, several in vitro functional studies have been conducted utilising myoblasts isolated from skeletal muscle tissue, and/or differentiated myotubes. However, as illustrated in this review, such studies have predominantly been conducted using cells derived from rodent skeletal muscle, which is known to have different fibre type composition and metabolic characteristics than human skeletal muscle [125]. Unfortunately therefore, much of functional and mode-of-action data generated using these rodent in vitro models may poorly translate to human skeletal muscle physiology. This is critical, since it is known that the greatest reason for late-stage failure of candidate drugs can be traced back to failure of preclinical target validation studies to translate to the clinic [126]. Furthermore, as highlighted in Table 2, the functional roles of novel adipokines such as FSTL1, SPARC and omentin-1 in mediating insulin sensitivity in skeletal muscle have yet to be studied.

To fill this gap, future studies on the expression profile of adipokines in humans need to be complimented with in vitro functional studies that utilise myoblasts and myotubes derived from human skeletal muscle biopsies or, where relevant, derived from muscle biopsies collected from T2D or insulin-resistant patients. Such studies will greatly facilitate identifying and validating novel therapeutic targets capable of improving glucose management that translate in the clinic.

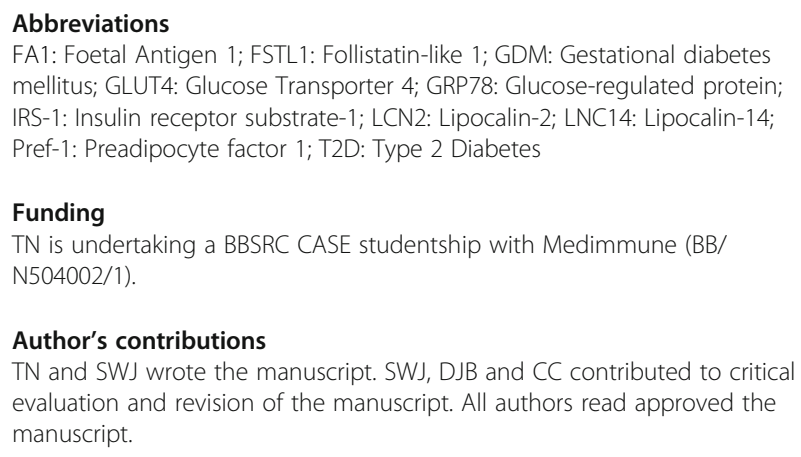

TN and SWJ wrote the manuscript. SWJ, DJB and CC contributed to critical evaluation and revision of the manuscript. All authors read approved the manuscript.

Ethics approval and consent to participate

Not applicable.

Competing interests

The authors declare they have no competing interests. 


\section{Publisher's Note}

Springer Nature remains neutral with regard to jurisdictional claims in published maps and institutional affiliations.

\section{Author details Research, Queen Elizabeth Hospital, Mindelsohn Way, Edgbaston, Birmingham B15 2TT, UK. \\ Received: 19 February 2018 Accepted: 2 May 2018 \\ Published online: 09 May 2018}

'MRC-ARUK Centre for Musculoskeletal Ageing Research, Medical School, Queen Elizabeth Hospital, University of Birmingham, Birmingham B15 2WB, UK. ${ }^{2}$ Medlmmune, Cardiovascular and Metabolic Disease (CVMD), Milstein Building, Granta Park, Cambridge CB21 6GH, UK. ${ }^{3}$ Institute of Inflammation and Ageing, MRC-Arthritis Research UK Centre for Musculoskeletal Ageing

\section{References}

1. Hex N, Bartlett C, Wright D, Taylor M, Varley D. Estimating the current and future costs of type 1 and type 2 diabetes in the UK, including direct health costs and indirect societal and productivity costs. Diabet Med. 2012;29:855-62.

2. Fowler MJ. Microvascular and macrovascular complications of diabetes. Clin Diab. 2008;26:77-82

3. Holman R. Metformin as first choice in oral diabetes treatment: the UKPDS experience. Journ Annu Diabetol Hotel Dieu. 2007:13-20.

4. Maruthur NM, Tseng E, Hutfless S, Wilson LM, Suarez-Cuervo C, Berger Z, Chu Y, lyoha E, Segal JB, Bolen S. Diabetes medications as monotherapy or metformin-based combination therapy for type 2 diabetes: a systematic review and meta-analysis. Ann Intern Med. 2016;164:740-51.

5. Consoli A, Formoso G. Do thiazolidinediones still have a role in treatment of type 2 diabetes mellitus? Diabetes Obes Metab. 2013:15:967-77.

6. Proks P, Reimann F, Green N, Gribble F, Ashcroft F. Sulfonylurea stimulation of insulin secretion. Diabetes. 2002;51(Suppl 3):S368-76.

7. Sola D, Rossi L, Schianca GP, Maffioli P, Bigliocca M, Mella R, Corliano F, Fra GP, Bartoli E, Derosa G. Sulfonylureas and their use in clinical practice. Arch Med Sci. 2015;11:840-8.

8. de Jager J, Kooy A, Lehert P, Wulffele MG, van der Kolk J, Bets D, Verburg J, Donker AJ, Stehouwer CD. Long term treatment with metformin in patients with type 2 diabetes and risk of vitamin B-12 deficiency: randomised placebo controlled trial. BMJ. 2010;340:c2181.

9. Boussageon R, Supper I, Bejan-Angoulvant T, Kellou N, Cucherat M, Boissel JP, Kassai B, Moreau A, Gueyffier F, Cornu C. Reappraisal of metformin efficacy in the treatment of type 2 diabetes: a meta-analysis of randomised controlled trials. PLoS Med. 2012;9:e1001204

10. Eppenga WL, Lalmohamed A, Geerts AF, Derijks HJ, Wensing M, Egberts A, De Smet PA, de Vries F. Risk of lactic acidosis or elevated lactate concentrations in metformin users with renal impairment: a population-based cohort study. Diabetes Care. 2014;37:2218-24.

11. Loke YK, Kwok CS, Singh S. Comparative cardiovascular effects of thiazolidinediones: systematic review and meta-analysis of observational studies. BMJ. 2011;342:d1309.

12. Gallagher AM, Smeeth L, Seabroke S, Leufkens HGM, van Staa TP. Risk of death and cardiovascular outcomes with Thiazolidinediones: a study with the general practice research database and secondary care data. PLoS One. 2011;6:e28157.

13. Nissen SE, Wolski K. Effect of rosiglitazone on the risk of myocardial infarction and death from cardiovascular causes. N Engl J Med. 2007;356:2457-71.

14. Utriainen T, Takala T, Luotolahti M, Ronnemaa T, Laine H, Ruotsalainen U, Haaparanta M, Nuutila P, Yki-Jarvinen $\mathrm{H}$. Insulin resistance characterizes glucose uptake in skeletal muscle but not in the heart in NIDDM. Diabetologia. 1998;41:555-9.

15. Pendergrass M, Bertoldo A, Bonadonna R, Nucci G, Mandarino L, Cobelli C, DeFronzo RA. Muscle glucose transport and phosphorylation in type 2 diabetic, obese nondiabetic, and genetically predisposed individuals. Am J Physiol Endocrinol Metab. 2007:292:E92-E100.

16. Thiebaud D, Jacot E, Defronzo RA, Maeder E, Jequier E, Felber J-P. The effect of graded doses of insulin on Total glucose uptake, glucose oxidation, and glucose storage in man. Diabetes. 1982;31:957-63.

17. Kershaw EE, Flier JS. Adipose tissue as an endocrine organ. J Clin Endocrinol Metab. 2004;89:2548-56.

18. Ahima RS, Flier JS. Adipose tissue as an endocrine organ. Trends Endocrinol Metab. 2000;11:327-32.
19. Fruhbeck G, Gomez-Ambrosi J, Muruzabal FJ, Burrell MA. The adipocyte: a model for integration of endocrine and metabolic signaling in energy metabolism regulation. Am J Physiol Endocrinol Metab. 2001;280:E827-47.

20. Zeyda M, Huber J, Prager G, Stulnig TM. Inflammation correlates with markers of T-cell subsets including regulatory $T$ cells in adipose tissue from obese patients. Obesity (Silver Spring). 2011;19:743-8.

21. Weisberg SP, McCann D, Desai M, Rosenbaum M, Leibel RL, Ferrante AW Jr. Obesity is associated with macrophage accumulation in adipose tissue. J Clin Invest. 2003;112:1796-808.

22. Nishimura S, Manabe I, Nagasaki M, Eto K, Yamashita H, Ohsugi M, Otsu M, Hara K, Ueki K, Sugiura S, et al. CD8+ effector T cells contribute to macrophage recruitment and adipose tissue inflammation in obesity. Nat Med. 2009:15:914-20.

23. Wentworth JM, Naselli G, Brown WA, Doyle L, Phipson B, Smyth GK, Wabitsch M, O'Brien PE, Harrison LC. Pro-inflammatory CD11c+CD206+ adipose tissue macrophages are associated with insulin resistance in human obesity. Diabetes. 2010;59:1648-56.

24. Lehr S, Hartwig S, Lamers D, Famulla S, Müller S, Hanisch F-G, Cuvelier C, Ruige J, Eckardt K, Ouwens DM, et al. Identification and validation of novel Adipokines released from primary human adipocytes. Mol Cell Proteomics. 2012:11:M111.010504.

25. Segal KR, Landt M, Klein S. Relationship between insulin sensitivity and plasma leptin concentration in lean and obese men. Diabetes. 1996;45:988-91.

26. Yadav A, Jyoti $P$, Jain SK, Bhattacharjee J. Correlation of adiponectin and leptin with insulin resistance: a pilot study in healthy north Indian population. Indian J Clin Biochem. 2011;26:193-6.

27. Sweeney G, Keen J, Somwar R, Konrad D, Garg R, Klip A. High leptin levels acutely inhibit insulin-stimulated glucose uptake without affecting glucose transporter 4 translocation in 16 rat skeletal muscle cells. Endocrinology. 2001:142:4806-12.

28. Berti L, Gammeltoft S. Leptin stimulates glucose uptake in C2C12 muscle cells by activation of ERK2. Mol Cell Endocrinol. 1999:157:121-30.

29. Ogawa Y, Masuzaki H, Hosoda K, Aizawa-Abe M, Suga J, Suda M, Ebihara K, Iwai H, Matsuoka N, Satoh N, et al. Increased glucose metabolism and insulin sensitivity in transgenic skinny mice overexpressing leptin. Diabetes. 1999:48:1822-9.

30. Yau SW, Henry BA, Russo VC, McConell GK, Clarke IJ, Werther GA, Sabin MA. Leptin enhances insulin sensitivity by direct and sympathetic nervous system regulation of muscle IGFBP-2 expression: evidence from nonrodent models. Endocrinology. 2014;155:2133-43.

31. Aleidi S, Issa A, Bustanji H, Khalil M, Bustanji Y. Adiponectin serum levels correlate with insulin resistance in type 2 diabetic patients. Saudi Pharm J. 2015:23:250-6.

32. Nayak BS, Ramsingh D, Gooding S, Legall G, Bissram S, Mohammed A, Raychaudhuri A, Sahadeo B, Pandohie V, Figaro K. Plasma adiponectin levels are related to obesity, inflammation, blood lipids and insulin in type 2 diabetic and non-diabetic Trinidadians. Prim Care Diabet. 2010:4:187-92.

33. Lee B, Shao J. Adiponectin and energy homeostasis. Rev Endocr Metab Disord. 2014:15:149-56.

34. Yoon MJ, Lee GY, Chung JJ, Ahn YH, Hong SH, Kim JB. Adiponectin increases fatty acid oxidation in skeletal muscle cells by sequential activation of AMP-activated protein kinase, p38 mitogen-activated protein kinase, and peroxisome proliferator-activated receptor alpha. Diabetes. 2006; 55:2562-70.

35. Yamauchi T, Kamon J, Minokoshi Y, Ito Y, Waki H, Uchida S, Yamashita S, Noda M, Kita S, Ueki K, et al. Adiponectin stimulates glucose utilization and fatty-acid oxidation by activating AMP-activated protein kinase. Nat Med. 2002:8:1288-95

36. Ceddia RB, Somwar R, Maida A, Fang X, Bikopoulos G, Sweeney G. Globular adiponectin increases GLUT4 translocation and glucose uptake but reduces glycogen synthesis in rat skeletal muscle cells. Diabetologia. 2005;48:132-9.

37. Kubota N, Terauchi Y, Yamauchi T, Kubota T, Moroi M, Matsui J, Eto K, Yamashita T, Kamon J, Satoh H, et al. Disruption of adiponectin causes insulin resistance and neointimal formation. J Biol Chem. 2002:277:25863-6.

38. Yamauchi T, Kamon J, Waki H, Terauchi Y, Kubota N, Hara K, Mori Y, Ide T, Murakami K, Tsuboyama-Kasaoka N, et al. The fat-derived hormone adiponectin reverses insulin resistance associated with both lipoatrophy and obesity. Nat Med. 2001;7:941-6.

39. Yano W, Kubota N, Itoh S, Kubota T, Awazawa M, Moroi M, Sugi K, Takamoto I, Ogata H, Tokuyama K, et al. Molecular mechanism of moderate insulin resistance in adiponectin-knockout mice. Endocr J. 2008;55:515-22. 
40. Kandasamy AD, Sung MM, Boisvenue JJ, Barr AJ, Dyck JRB. Adiponectin gene therapy ameliorates high-fat, high-sucrose diet-induced metabolic perturbations in mice. Nutr Diabetes. 2012;2:e45.

41. Chen MB, McAinch AJ, Macaulay SL, Castelli LA, O'Brien PE, Dixon JB, CameronSmith D, Kemp BE, Steinberg GR. Impaired activation of AMP-kinase and fatty acid oxidation by globular adiponectin in cultured human skeletal muscle of obese type 2 diabetics. J Clin Endocrinol Metab. 2005;90:3665-72.

42. Steppan CM, Bailey ST, Bhat S, Brown EJ, Banerjee RR, Wright CM, Patel HR, Ahima RS, Lazar MA. The hormone resistin links obesity to diabetes. Nature. 2001;409:307-12

43. Bokarewa M, Nagaev I, Dahlberg L, Smith U, Tarkowski A. Resistin, an Adipokine with potent Proinflammatory properties. J Immunol. 2005;174:5789-95.

44. Jiang CY, Wang W, Tang JX, Yuan ZR. The adipocytokine resistin stimulates the production of proinflammatory cytokines TNF-alpha and IL-6 in pancreatic acinar cells via NF-kappaB activation. J Endocrinol Investig. 2013;36:986-92.

45. Azuma K, Katsukawa F, Oguchi S, Murata M, Yamazaki H, Shimada A, Saruta T. Correlation between serum Resistin level and adiposity in obese individuals. Obes Res. 2003;11:997-1001

46. Gharibeh MY, Al Tawallbeh GM, Abboud MM, Radaideh A, Alhader AA Khabour OF. Correlation of plasma resistin with obesity and insulin resistance in type 2 diabetic patients. Diabetes Metab. 2010;36:443-9.

47. Fan HQ, Gu N, Liu F, Fei L, Pan XQ, Guo M, Chen RH, Guo XR. Prolonged exposure to resistin inhibits glucose uptake in rat skeletal muscles. Acta Pharmacol Sin. 2007;28:410-6

48. Palanivel R, Maida A, Liu Y, Sweeney G. Regulation of insulin signalling, glucose uptake and metabolism in rat skeletal muscle cells upon prolonged exposure to resistin. Diabetologia. 2006;49:183-90.

49. Sheng $\mathrm{CH}$, Du ZW, Song Y, Wu XD, Zhang YC, Wu M, Wang Q, Zhang GZ. Human resistin inhibits myogenic differentiation and induces insulin resistance in myocytes. Biomed Res Int. 2013;2013:804632.

50. Jia SH, Li Y, Parodo J, Kapus A, Fan L, Rotstein OD, Marshall JC. Pre-B cell colony-enhancing factor inhibits neutrophil apoptosis in experimental inflammation and clinical sepsis. J Clin Investig. 2004;113:1318-27.

51. Samal B, Sun Y, Stearns G, Xie C, Suggs S, McNiece I. Cloning and characterization of the CDNA encoding a novel human pre-B-cell colonyenhancing factor. Mol Cell Biol. 1994;14:1431-7.

52. Terra X, Auguet T, Quesada I, Aguilar C, Luna AM, Hernandez M, Sabench F, Porras JA, Martinez S, Lucas A, et al. Increased levels and adipose tissue expression of visfatin in morbidly obese women: the relationship with proinflammatory cytokines. Clin Endocrinol. 2012;77:691-8.

53. Esteghamati A, Alamdari A, Zandieh A, Elahi S, Khalilzadeh O, Nakhjavani M, Meysamie A. Serum visfatin is associated with type 2 diabetes mellitus independent of insulin resistance and obesity. Diabetes Res Clin Pract. 2011;91:154-8.

54. Catalan V, Gomez-Ambrosi J, Rodriguez A, Ramirez B, Silva C, Rotellar F, Cienfuegos JA, Salvador J, Fruhbeck G. Association of increased visfatin/ PBEF/NAMPT circulating concentrations and gene expression levels in peripheral blood cells with lipid metabolism and fatty liver in human morbid obesity. Nutr Metab Cardiovasc Dis. 2011;21:245-53.

55. Chang YH, Chang DM, Lin KC, Shin SJ, Lee YJ. Visfatin in overweight/obesity, type 2 diabetes mellitus, insulin resistance, metabolic syndrome and cardiovascular diseases: a meta-analysis and systemic review. Diabetes Metab Res Rev. 2011;27:515-27.

56. Sun Q, Li L, Li R, Yang M, Liu H, Nowicki MJ, Zong H, Xu J, Yang G. Overexpression of visfatin/PBEF/Nampt alters whole-body insulin sensitivity and lipid profile in rats. Ann Med. 2009:41:311-20.

57. Lee JO, Kim N, Lee HJ, Lee YW, Kim JK, Kim HI, Lee SK, Kim SJ, Park SH, Kim HS. Visfatin, a novel adipokine, stimulates glucose uptake through the Ca2 + -dependent AMPK-p38 MAPK pathway in C2C12 skeletal muscle cells. J Mol Endocrinol. 2015;54:251-62

58. Hida K, Wada J, Zhang H, Hiragushi K, Tsuchiyama Y, Shikata K, Makino H. Identification of genes specifically expressed in the accumulated visceral adipose tissue of OLETF rats. J Lipid Res. 2000:41:1615-22.

59. Hida K, Wada J, Eguchi J, Zhang H, Baba M, Seida A, Hashimoto I, Okada T, Yasuhara A, Nakatsuka A, et al. Visceral adipose tissue-derived serine protease inhibitor: a unique insulin-sensitizing adipocytokine in obesity. Proc Natl Acad Sci U S A. 2005;102:10610-5.

60. Heiker JT, Klöting N, Kovacs P, Kuettner EB, Sträter N, Schultz S, Kern M, Stumvoll M, Blüher M, Beck-Sickinger AG. Vaspin inhibits kallikrein 7 by serpin mechanism. Cell Mol Life Sci. 2013;70:2569-83.

61. Klöting $N$, Kovacs $P$, Kern M, Heiker JT, Fasshauer M, Schön MR, Stumvoll M, Beck-Sickinger AG, Blüher M. Central vaspin administration acutely reduces food intake and has sustained blood glucose-lowering effects. Diabetologia. 2011;54:1819-23.

62. Nakatsuka A, Wada J, Iseda I, Teshigawara S, Higashio K, Murakami K, Kanzak M, Inoue K, Terami T, Katayama A, et al. Vaspin is an Adipokine ameliorating ER stress in obesity as a ligand for cell-surface GRP78/MTJ-1 complex. Diabetes. 2012;61:2823-32.

63. Klöting N, Berndt J, Kralisch S, Kovacs P, Fasshauer M, Schön MR, Stumvoll M, Blüher M. Vaspin gene expression in human adipose tissue: association with obesity and type 2 diabetes. Biochem Biophys Res Commun. 2006;339:430-6.

64. Schultz S, Saalbach A, Heiker John T, Meier R, Zellmann T, Simon Jan C, Beck-Sickinger Annette G. Proteolytic activation of prochemerin by kallikrein 7 breaks an ionic linkage and results in C-terminal rearrangement. Biochem J. 2013;452:271-80.

65. Aust G, Richter O, Rohm S, Kerner C, Hauss J, Kloting N, Ruschke K, Kovacs P Youn BS, Bluher M. Vaspin serum concentrations in patients with carotid stenosis. Atherosclerosis. 2009;204:262-6.

66. Jian W, Peng W, Xiao S, Li H, Jin J, Qin L, Dong Y, Su Q. Role of serum Vaspin in progression of type 2 diabetes: a 2-year cohort study. PLoS One. 2014;9:e94763.

67. Teshigawara S, Wada J, Hida K, Nakatsuka A, Eguchi J, Murakami K, Kanzak M, Inoue K, Terami T, Katayama A, et al. Serum Vaspin concentrations are closely related to insulin resistance, and rs77060950 at SERPINA12 genetically defines distinct group with higher serum levels in Japanese population. J Clin Endocrinol Metab. 2012;97:E1202-7.

68. Youn BS, Kloting N, Kratzsch J, Lee N, Park JW, Song ES, Ruschke K, Oberbach A, Fasshauer M, Stumvoll M, Bluher M. Serum vaspin concentrations in human obesity and type 2 diabetes. Diabetes. 2008;57:372-7.

69. Badman MK, Pissios P, Kennedy AR, Koukos G, Flier JS, Maratos-Flier E. Hepatic fibroblast growth factor 21 is regulated by PPARa and is a key mediator of hepatic lipid metabolism in Ketotic states. Cell Metab. 2007:5:426-37.

70. Badman MK, Koester A, Flier JS, Kharitonenkov A, Maratos-Flier E. Fibroblast growth factor 21-deficient mice demonstrate impaired adaptation to ketosis. Endocrinology. 2009;150:4931-40.

71. So WY, Leung PS. Fibroblast growth factor 21 as an emerging therapeutic target for type 2 diabetes mellitus. Med Res Rev. 2016;36:672-704.

72. Zhang X, Yeung DCY, Karpisek M, Stejskal D, Zhou Z-G, Liu F, Wong RLC, Chow W-S, Tso AWK, Lam KSL, Xu A. Serum FGF21 levels are increased in obesity and are independently associated with the metabolic syndrome in humans. Diabetes. 2008;57:1246.

73. Semba RD, Sun K, Egan JM, Crasto C, Carlson OD, Ferrucci L. Relationship of serum fibroblast growth factor 21 with abnormal glucose metabolism and insulin resistance: the Baltimore longitudinal study of aging. J Clin Endocrinol Metab. 2012;97:1375-82.

74. Reinehr T, Woelfle J, Wunsch R, Roth CL. Fibroblast growth factor 21 (FGF21) and its relation to obesity, metabolic syndrome, and nonalcoholic fatty liver in children: a longitudinal analysis. J Clin Endocrinol Metab. 2012;97: 2143-50.

75. Chavez AO, Molina-Carrion M, Abdul-Ghani MA, Folli F, DeFronzo RA, Tripathy D. Circulating fibroblast growth Factor-21 is elevated in impaired glucose tolerance and type 2 diabetes and correlates with muscle and hepatic insulin resistance. Diabetes Care. 2009;32:1542.

76. Lin Z, Tian H, Lam KS, Lin S, Hoo RC, Konishi M, Itoh N, Wang Y, Bornstein SR, XU A, Li X. Adiponectin mediates the metabolic effects of FGF21 on glucose homeostasis and insulin sensitivity in mice. Cell Metab. 2013;17:779-89.

77. Sarruf DA, Thaler JP, Morton GJ, German J, Fischer JD, Ogimoto K, Schwartz MW. Fibroblast growth factor 21 action in the brain increases energy expenditure and insulin sensitivity in obese rats. Diabetes. 2010;59:1817-24.

78. Kharitonenkov A, Wroblewski VJ, Koester A, Chen Y-F, Clutinger CK, Tigno $X T$, Hansen BC, Shanafelt AB, Etgen GJ. The metabolic state of diabetic monkeys is regulated by fibroblast growth Factor-21. Endocrinology. 2007; 148:774-81.

79. Thompson WC, Zhou Y, Talukdar S, Musante CJ. PF-05231023, a long-acting FGF21 analogue, decreases body weight by reduction of food intake in non-human primates. J Pharmacokinet Pharmacodyn. 2016:43:411-25.

80. Talukdar S, Zhou Y, Li D, Rossulek M, Dong J, Somayaji V, Weng Y, Clark R, Lanba A, Owen BM, et al. A long-acting FGF21 molecule, PF-05231023, decreases body weight and improves lipid profile in non-human Primates and type 2 diabetic subjects. Cell Metab. 2016;23:427-40.

81. Gaich G, Chien JY, Fu H, Glass LC, Deeg MA, Holland WL, Kharitonenkov A, Bumol T, Schilske HK, Moller DE. The effects of LY2405319, an FGF21 analog, in obese human subjects with type 2 diabetes. Cell Metab. 2013;18:333-40. 
82. Kim JH, Bae KH, Choi YK, Go Y, Choe M, Jeon YH, Lee HW, Koo SH, Perfield JW 2nd, Harris RA, et al. Fibroblast growth factor 21 analogue LY2405319 lowers blood glucose in streptozotocin-induced insulin-deficient diabetic mice by restoring brown adipose tissue function. Diabetes Obes Metab. 2015;17:161-9.

83. Lee JH, Kang YE, Chang JY, Park KC, Kim HW, Kim JT, Kim HJ, Yi HS, Shong M, Chung HK, Kim KS. An engineered FGF21 variant, LY2405319, can prevent non-alcoholic steatohepatitis by enhancing hepatic mitochondrial function. Am J Transl Res. 2016:8:4750-63.

84. Degirolamo C, Sabba C, Moschetta A. Therapeutic potential of the endocrine fibroblast growth factors FGF19, FGF21 and FGF23. Nat Rev Drug Discov. 2016;15:51-69.

85. Kolumam G, Chen MZ, Tong R, Zavala-Solorio J, Kates L, van Bruggen N, Ross J, Wyatt SK, Gandham VD, Carano RA, et al. Sustained Brown fat stimulation and insulin sensitization by a humanized bispecific antibody agonist for fibroblast growth factor receptor 1/betaKlotho complex. EBioMedicine. 2015;2:730-43.

86. Mashili FL, Austin RL, Deshmukh AS, Fritz T, Caidahl K, Bergdahl K, Zierath JR, Chibalin AV, Moller DE, Kharitonenkov A, Krook A. Direct effects of FGF21 on glucose uptake in human skeletal muscle: implications for type 2 diabetes and obesity. Diabetes Metab Res Rev. 2011;27:286-97.

87. Lee MS, Choi S-E, Ha ES, An S-Y, Kim TH, Han SJ, Kim HJ, Kim DJ, Kang Y, Lee K-W. Fibroblast growth factor-21 protects human skeletal muscle myotubes from palmitate-induced insulin resistance by inhibiting stress kinase and NF-kB. Metabolism. 2012;61:1142-51.

88. De Henau O, Degroot G-N, Imbault V, Robert V, De Poorter C, McHeik S, Galés C, Parmentier M, Springael J-Y. Signaling properties of Chemerin receptors CMKLR1, GPR1 and CCRL2. PLoS One. 2016;11:e0164179.

89. Wittamer V, Franssen J-D, Vulcano M, Mirjolet J-F, Le Poul E, Migeotte I, Brézillon S, Tyldesley R, Blanpain C, Detheux M, et al. Specific recruitment of antigen-presenting cells by Chemerin, a novel processed ligand from human inflammatory fluids. J Exp Med. 2003;198:977.

90. Goralski KB, McCarthy TC, Hanniman EA, Zabel BA, Butcher EC, Parlee SD, Muruganandan S, Sinal CJ. Chemerin, a novel adipokine that regulates adipogenesis and adipocyte metabolism. J Biol Chem. 2007;282:28175-88.

91. Roh SG, Song SH, Choi KC, Katoh K, Wittamer V, Parmentier M, Sasaki S. Chemerin-a new adipokine that modulates adipogenesis via its own receptor. Biochem Biophys Res Commun. 2007;362:1013-8.

92. Zylla S, Pietzner M, Kuhn JP, Volzke H, Dorr M, Nauck M, Friedrich N. Serum chemerin is associated with inflammatory and metabolic parameters-results of a population-based study. Obesity (Silver Spring). 2017;25:468-75.

93. Li Y, Shi B, Li S. Association between serum Chemerin concentrations and clinical indices in obesity or metabolic syndrome: a meta-analysis. PLoS One. 2014;9:e113915

94. Sell H, Divoux A, Poitou C, Basdevant A, Bouillot JL, Bedossa P, Tordjman J, Eckel J, Clement K. Chemerin correlates with markers for fatty liver in morbidly obese patients and strongly decreases after weight loss induced by bariatric surgery. J Clin Endocrinol Metab. 2010;95:2892-6.

95. Sell H, Laurencikiene J, Taube A, Eckardt K, Cramer A, Horrighs A, Arner P, Eckel J. Chemerin is a novel adipocyte-derived factor inducing insulin resistance in primary human skeletal muscle cells. Diabetes. 2009:58:2731-40.

96. Becker M, Rabe K, Lebherz C, Zugwurst J, Göke B, Parhofer KG, Lehrke M, Broedl UC. Expression of human Chemerin induces insulin resistance in the skeletal muscle but does not affect weight, lipid levels, and atherosclerosis in LDL receptor knockout mice on high-fat diet. Diabetes. 2010;59:2898-903.

97. Ernst MC, Issa M, Goralski KB, Sinal CJ. Chemerin exacerbates glucose intolerance in mouse models of obesity and diabetes. Endocrinology. 2010;151:1998-2007.

98. Takahashi M, Okimura Y, Iguchi G, Nishizawa H, Yamamoto M, Suda K, Kitazawa R, Fujimoto W, Takahashi K, Zolotaryov FN, et al. Chemerin regulates $\beta$-cell function in mice. Sci Rep. 2011;1:123.

99. Huang Z, Xie X. Chemerin induces insulin resistance in C2C12 cells through nuclear factor-kappaB pathway-mediated inflammatory reaction. Xi Bao Yu Fen Zi Mian Yi Xue Za Zhi. 2015;31:725-9.

100. Wang Y, Sul HS. Ectodomain shedding of Preadipocyte factor 1 (Pref-1) by tumor necrosis factor alpha converting enzyme (TACE) and inhibition of adipocyte differentiation. Mol Cell Biol. 2006;26:5421-35.

101. Chacon MR, Miranda M, Jensen CH, Fernandez-Real JM, Vilarrasa N, Gutierrez C, Naf S, Gomez JM, Vendrell J. Human serum levels of fetal antigen 1 (FA1/ DIk1) increase with obesity, are negatively associated with insulin sensitivity and modulate inflammation in vitro. Int J Obes. 2008;32:1122-9.

102. Kavalkova P, Touskova V, Roubicek T, Trachta P, Urbanova M, Drapalova J, Haluzikova D, Mraz M, Novak D, Matoulek M, et al. Serum preadipocyte factor- 1 concentrations in females with obesity and type 2 diabetes mellitus: the influence of very low calorie diet, acute hyperinsulinemia, and fenofibrate treatment. Horm Metab Res. 2013;45:820-6.

103. Moon YS, Smas CM, Lee K, Villena JA, Kim KH, Yun EJ, Sul HS. Mice lacking paternally expressed Pref-1/Dlk1 display growth retardation and accelerated adiposity. Mol Cell Biol. 2002;22:5585-92.

104. Villena JA, Kim KH, Sul HS. Pref-1 and ADSF/resistin: two secreted factors inhibiting adipose tissue development. Horm Metab Res. 2002;34:664-70.

105. Villena JA, Choi CS, Wang Y, Kim S, Hwang Y-J, Kim Y-B, Cline G, Shulman Gl, Sul HS. Resistance to high-fat diet-induced obesity but exacerbated insulin resistance in mice overexpressing Preadipocyte Factor-1 (Pref-1): a new model of partial lipodystrophy. Diabetes. 2008;57:3258-66.

106. Abdallah BM, Beck-Nielsen H, Gaster M. FA1 induces pro-inflammatory and anti-Adipogenic pathways/markers in human Myotubes established from lean, obese, and type 2 diabetic subjects but not insulin resistance. Front Endocrinol. 2013;4:45.

107. Miyamae T, Marinov AD, Sowders D, Wilson DC, Devlin J, Boudreau R, Robbins P, Hirsch R. Follistatin-like Protein-1 is a novel Proinflammatory molecule. J Immunol. 2006;177:4758-62.

108. Fan N, Sun H, Wang Y, Wang Y, Zhang L, Xia Z, Peng L, Hou Y, Shen W, Liu $\mathrm{R}$, et al. Follistatin-like 1: a potential mediator of inflammation in obesity. Mediat Inflamm. 2013;2013:752519.

109. Wu Y, Zhou S, Smas CM. Downregulated expression of the secreted glycoprotein Follistatin-like 1 (Fstl1) is a robust Hallmark of Preadipocyte to adipocyte conversion. Mech Dev. 2010;127:183-202.

110. Gorgens SW, Raschke S, Holven KB, Jensen J, Eckardt K, Eckel J. Regulation of follistatin-like protein 1 expression and secretion in primary human skeletal muscle cells. Arch Physiol Biochem. 2013;119:75-80.

111. Shen $Y$, Zhao Y, Yuan L, Yi W, Zhao R, Yi Q, Yong T. SPARC is over-expressed in adipose tissues of diet-induced obese rats and causes insulin resistance in 3T3-L1 adipocytes. Acta Histochem. 2014;116:158-66.

112. Chavey C, Boucher J, Monthouël-Kartmann M-N, Sage EH, Castan-Laurell I, Valet $\mathrm{P}$, Tartare-Deckert S, Van Obberghen E. Regulation of secreted protein acidic and rich in cysteine during adipose conversion and adipose tissue hyperplasia. Obesity. 2006;14:1890-7.

113. Kos K, Wong S, Tan B, Gummesson A, Jernas M, Franck N, Kerrigan D, Nystrom FH, Carlsson LM, Randeva HS, et al. Regulation of the fibrosis and angiogenesis promoter SPARC/osteonectin in human adipose tissue by weight change, leptin, insulin, and glucose. Diabetes. 2009;58:1780-8.

114. Xu L, Ping F, Yin J, Xiao X, Xiang H, Ballantyne CM, Wu H, Li M. Elevated plasma SPARC levels are associated with insulin resistance, dyslipidemia, and inflammation in gestational diabetes mellitus. PLoS One. 2013;8:e81615.

115. Wolf RM, Steele KE, Peterson LA, Magnuson TH, Schweitzer MA, Wong GW. Lower circulating C1q/TNF-related Protein-3 (CTRP3) levels are associated with obesity: a cross-sectional study. PLoS One. 2015;10:e0133955.

116. Deng W, Li C, Zhang Y, Zhao J, Yang M, Tian M, Li L, Zheng Y, Chen B, Yang G. Serum C1q/TNF-related protein-3 (CTRP3) levels are decreased in obesity and hypertension and are negatively correlated with parameters of insulin resistance. Diabetol Metab Syndr. 2015;7:33.

117. Weigert J, Neumeier M, Schäffler A, Fleck M, Schölmerich J, Schütz C, Buechler C. The adiponectin paralog CORS-26 has anti-inflammatory properties and is produced by human monocytic cells. FEBS Lett. 2005;579:5565-70.

118. Kopp A, Bala M, Buechler C, Falk W, Gross P, Neumeier M, Scholmerich J, Schaffler A C1q/TNF-related protein-3 represents a novel and endogenous lipopolysaccharide antagonist of the adipose tissue. Endocrinology. 2010;151:5267-78.

119. Tsuji S, Uehori J, Matsumoto M, Suzuki Y, Matsuhisa A, Toyoshima K, Seya T. Human intelectin is a novel soluble lectin that recognizes galactofuranose in carbohydrate chains of bacterial cell wall. J Biol Chem. 2001;276:23456-63.

120. de Souza Batista CM, Yang RZ, Lee MJ, Glynn NM, Yu DZ, Pray J, Ndubuizu K, Patil S, Schwartz A, Kligman M, et al. Omentin plasma levels and gene expression are decreased in obesity. Diabetes. 2007;56:1655-61.

121. Pan HY, Guo L, Li Q. Changes of serum omentin-1 levels in normal subjects and in patients with impaired glucose regulation and with newly diagnosed and untreated type 2 diabetes. Diabetes Res Clin Pract. 2010;88:29-33.

122. Tan BK, Adya R, Farhatullah S, Lewandowski KC, O'Hare P, Lehnert $H$, Randeva HS. Omentin-1, a novel Adipokine, is decreased in overweight insulin-resistant women with polycystic ovary syndrome. Diabetes. 2008;57:801.

123. Yang RZ, Lee MJ, Hu H, Pray J, Wu HB, Hansen BC, Shuldiner AR, Fried SK, McLenithan JC, Gong DW. Identification of omentin as a novel depotspecific adipokine in human adipose tissue: possible role in modulating insulin action. Am J Physiol Endocrinol Metab. 2006;290:E1253-61. 
124. Lee JT, Huang Z, Pan K, Zhang HJ, Woo CW, Xu A, Wong CM. Adipose-derived lipocalin 14 alleviates hyperglycaemia by suppressing both adipocyte glycerol efflux and hepatic gluconeogenesis in mice. Diabetologia. 2016;59:604-13.

125. Garland T Jr, Schutz H, Chappell MA, Keeney BK, Meek TH, Copes LE, Acosta W, Drenowatz C, Maciel RC, van Dijk G, et al. The biological control of voluntary exercise, spontaneous physical activity and daily energy expenditure in relation to obesity: human and rodent perspectives. J Exp Biol. 2011;214:206-29.

126. Mak IWY, Evaniew N, Ghert M. Lost in translation: animal models and clinical trials in cancer treatment. Am J Transl Res. 2014;6:114-8.

127. Considine RV, Sinha MK, Heiman ML, Kriauciunas A, Stephens TW, Nyce MR, Ohannesian JP, Marco CC, McKee LJ, Bauer TL, et al. Serum immunoreactiveleptin concentrations in normal-weight and obese humans. N Engl J Med. 1996;334:292-5

128. Yaspelkis BB 3rd, Davis JR, Saberi M, Smith TL, Jazayeri R, Singh M, Fernandez V, Trevino B, Chinookoswong N, Wang J, et al. Leptin administration improves skeletal muscle insulin responsiveness in diet-induced insulin-resistant rats. Am J Physiol Endocrinol Metab. 2001;280:E130-42.

129. Doh KO, Park JO, Kim YW, Park SY, Jeong JH, Jeon JR, Lee SK, Kim JY. Effect of leptin on insulin resistance of muscle-direct or indirect? Physiol Res. 2006;55:413-9.

130. Bates SH, Gardiner JV, Jones RB, Bloom SR, Bailey CJ. Acute stimulation of glucose uptake by leptin in 16 muscle cells. Horm Metab Res. 2002;34:111-5.

131. Fang X, Fetros J, Dadson KE, Xu A, Sweeney G. Leptin prevents the metabolic effects of adiponectin in L6 myotubes. Diabetologia. 2009;52:2190-200.

132. Jiang Y, Lu L, Hu Y, Li Q, An C, Yu X, Shu L, Chen A, Niu C, Zhou L, Yang Z. Resistin induces hypertension and insulin resistance in mice via a TLR4dependent pathway. Sci Rep. 2016;6:22193.

133. Muse ED, Obici S, Bhanot S, Monia BP, McKay RA, Rajala MW, Scherer PE, Rossetti $\mathrm{L}$. Role of resistin in diet-induced hepatic insulin resistance. J Clin Investig. 2004;114:232-9.

134. Haider DG, Schindler K, Schaller G, Prager G, Wolzt M, Ludvik B. Increased plasma Visfatin concentrations in morbidly obese subjects are reduced after gastric banding. J Clin Endocrinol Metab. 2006;91:1578-81.

135. Berndt J, Klöting N, Kralisch S, Kovacs P, Fasshauer M, Schön MR, Stumvoll M, Blüher M. Plasma Visfatin concentrations and fat depot-specific mRNA expression in humans. Diabetes. 2005;54:2911-6.

136. Retnakaran R, Youn BS, Liu Y, Hanley AJ, Lee NS, Park JW, Song ES, Vu V, Kim $W$, Tungtrongchitr $R$, et al. Correlation of circulating full-length visfatin (PBEF/NAMPT) with metabolic parameters in subjects with and without diabetes: a cross-sectional study. Clin Endocrinol. 2008:69:885-93.

137. Harasim E, Chabowski A, Gorski J. Lack of downstream insulin-mimetic effects of visfatin/eNAMPT on glucose and fatty acid metabolism in skeletal muscles. Acta Physiol (Oxf). 2011;202:21-8.

138. Chakaroun R, Raschpichler M, Kloting N, Oberbach A, Flehmig G, Kern M Schon MR, Shang E, Lohmann T, Dressler M, et al. Effects of weight loss and exercise on chemerin serum concentrations and adipose tissue expression in human obesity. Metabolism. 2012;61:706-14.

139. Wagner RM, Sivagnanam K, Clark WA, Peterson JM. Divergent relationship of circulating CTRP3 levels between obesity and gender: a cross-sectional study. PeerJ. 2016;4:e2573.

140. Peterson JM, Wei Z, Wong GW. C1q/TNF-related protein-3 (CTRP3), a novel adipokine that regulates hepatic glucose output. J Biol Chem. 2010;285: 39691-701.

141. Peterson JM, Seldin MM, Wei Z, Aja S, Wong GW. CTRP3 attenuates dietinduced hepatic steatosis by regulating triglyceride metabolism. Am 」 Physiol Gastrointest Liver Physiol. 2013;305:G214-24.

142. Li X, Jiang L, Yang M, Wu YW, Sun JZ, Sun SX. CTRP3 improves the insulin sensitivity of 3T3-L1 adipocytes by inhibiting inflammation and ameliorating insulin signalling transduction. Endokrynol Pol. 2014;65:252-8.

143. Graham TE, Yang Q, Blüher M, Hammarstedt A, Ciaraldi TP, Henry RR, Wason CJ, Oberbach A, Jansson P-A, Smith U, Kahn BB. Retinol-binding protein 4 and insulin resistance in lean, obese, and diabetic subjects. N Engl J Med. 2006;354:2552-63.

144. Yang Q, Graham TE, Mody N, Preitner F, Peroni OD, Zabolotny JM, Kotani K, Quadro L, Kahn BB. Serum retinol binding protein 4 contributes to insulin resistance in obesity and type 2 diabetes. Nature. 2005;436:356-62.

145. Zemany L, Bhanot S, Peroni OD, Murray SF, Moraes-Vieira PM, Castoldi A, Manchem P, Guo S, Monia BP, Kahn BB. Transthyretin antisense oligonucleotides lower circulating RBP4 levels and improve insulin sensitivity in obese mice. Diabetes. 2015;64:1603-14.
146. Cătoi AF, Suciu Ş, Pârvu AE, Copăescu C, Galea RF, Buzoianu AD, Vereşiu IA, Cătoi C, Pop ID. Increased chemerin and decreased omentin-1 levels in morbidly obese patients are correlated with insulin resistance, oxidative stress and chronic inflammation. Clujul Medical. 2014;87:19-26.

147. Jialal I, Devaraj S, Kaur H, Adams-Huet B, Bremer AA. Increased Chemerin and decreased Omentin-1 in both adipose tissue and plasma in nascent metabolic syndrome. J Clin Endocrinol Metab. 2013;98:E514-7.

\section{Ready to submit your research? Choose BMC and benefit from:}

- fast, convenient online submission

- thorough peer review by experienced researchers in your field

- rapid publication on acceptance

- support for research data, including large and complex data types

- gold Open Access which fosters wider collaboration and increased citations

- maximum visibility for your research: over $100 \mathrm{M}$ website views per year

At BMC, research is always in progress.

Learn more biomedcentral.com/submissions 